\title{
Yenidoğan ve Süt Çocuklarında Girişimsel Ağrı ve Non-Farmakolojik Yönetimi
}

\author{
Interventional Pain and Non-Pharmacologic Management Among Neonates and Infants
}

Derya Emre YAVUZ ${ }^{1}$, Şule Ecevit ALPAR ${ }^{1}$

1. Marmara Üniversitesi, İstanbul

\section{$\ddot{O Z Z T}$}

Ağrı sağllk durumunu direk etkileyen kontrol edilmediğinde hayatın bütün alanlarında olumsuz sonuçlar doğuran bir sorundur. Tüm çocuklara doğumdan itibaren bir dizi girișimsel ağrılı işlem uygulanmaktadır. Kan alma, enjeksiyon, aşı gibi girișimsel işlemler çocukların en büyük ağrl kaynaklarındandır. A ğrının yarattığı travma çocuklarda başta iğne fobisi olmak üzere, assi uygulamalarında aksaklık, tedaviye uyumda yetersizlik sebebi olabilir ve bu durumlar önlenebilir birçok hastalıkta salgınlara neden olarak çocukları savunmasız birakabilir. Özellikle beyin gelişimin hızlı olduğu süt çocukluğu döneminde ağrının gelişimsel ve emosyonel etkilerini gidermek için girişimsel ișlem ağrıları iyi yönetilmelidir. Ağrı yönetiminde farmakolojik ve non-farmakolojik pek çok yaklaşım vardır. Farmakolojik yöntemlerin deneyimli personel tarafindan uygulanma zorunluluğu, komplikasyon riski ve maliyeti nedeniyle kullanımın nerdeyse imkansızdır. Sükroz, kıvırarak tutmak, anne kucă̆l, kanguru bakımı, emzik vermek, taktil uyarı, emzirme, kundaklama kullanılan yenidoğan ve süt çocukları için kullanılan non-farmakolojik yöntemlerdendir. Bu makale yenidoğan ve süt çocuğunda girișimsel işlem ağrıları ve bunun non-farmakolojik yönetiminin önemini vurgulamak için yazılmıștır.

Anahtar Kelimeler: yenidoğan, süt çocuğu, girişimsel ağrl

\section{SUMMARY}

The pain is a problem that directly affects the health status and leading to negative results in every domain of life when not controlled. All of the children receive a series of painful interventions since the moment of birth. The interventional procedures such as blood-letting and vaccination are the most important pain sources for the children. The trauma that pain creates might cause unconformity with the vaccination and the lack of adherence to therapy. These conditions might cause outbreaks in many preventable diseases, and leave the children defenseless. Especially in the infancy period, in which the brain development is fast, the pains arising from interventional procedures should be well-managed in order to eliminate the developmental and emotional effects of pain. In pain management, there are many approaches both pharmacological and non-pharmacological. It is almost impossible to use the pharmacological methods due to the reasons such as the requirement of application by experienced personnel, the complication risk, and the costs. Some of the non-pharmacological methods used for neonates and infants are sucrose, holding in inclined position, kangaroo care, mother's bosom, lactation, tactile stimulation, and swaddling. This paper was prepared in order to discuss the interventional procedure pains among the neonates and infants and the importance of non-pharmacological management of these pains.

Keywords: neonate, infant, interventional pain

İletişim

Sorumlu Yazar: Derya Emre YAVUZ

Adres: Marmara Ünv., Eğitim Mh. Fahrettin Kerim Gökay Cd. MÜ Göztepe Kampüsü, Göztepe, Kadıköy, İstanbul Tel: +90 (530) 4669668

E-Posta: deryaemreyavuz@gmail.com

Makale Geliş: 14.09.2017

Makale Kabul: 19.09.2017

DOI: http://dx.doi.org/10.16948/zktipb.338176

\section{GíRIS}

Ağrı; vücudun herhangi bir yerinden başlayan, organik bir nedene bağlı olan veya olmayan, kişinin geçmişteki yaşantıları ile ilgili, sensoryal, emosyonel, hoş olmayan bir deneyimdir (1). Ağrı oluşumu ile ilgili Melzack ve Wall tarafindan geliștirilen "kapı kontrol" teorisine göre spinal kordonun dorsal boynuzları sadece pasif ileten değil aynı zamanda iletileri değiştirebilen aktif bölgelerden oluşur (2). Bireyler arası ağrı algısı farklıdır hatta aynı birey zamanla ağrıyı farklı düzeyde hissedilebilir (3).

Ağrı algısının özellikle yenidoğanda gelişmemiş ve ağr1 deneyimi için belleklerinin olmadığ1 görüșü uzun süre kabul görse de bilimsel çalışmalar fetüste dahi kortikal ağrı algısının olduğunu, ağrının nereden kaynaklandığını ayırt edebildiğini kanıtlamıştır $(4,5)$. Yaş küçüldükçe hissedilen ağrı artar (6). Özellikle aşı enjeksiyonlarının uzun dönemde davranış değişikliğine yol açtığı gösterilmiştir (7). Bebeğin yaşadığı ağrı, davranışlarını, aile bebek etkileşimini, dıș dünyaya uyumunu ve beyni etkiler, büyümeyi yavaşlatır (8).

Ağrı yönetimi için farmakolojik, davranışsal ve fiziksel yöntemler kullanılabilir. Farmakolojik yöntemlerin deneyimli personel tarafindan uygulanma zorunluluğu, komplikasyon riski ve maliyeti nedeniyle kullanımını nerdeyse imkansızdır.

Çocukların en sık yaşadıkları iyatrojenik ağrının intramüsküler (IM) aşı uygulamalarından kaynaklanması nedeniyle son yıllarda IM aşı ağrısını azaltmaya yönelik araştırmalar artmıştır (9). Dikkat dağıtma ilaçsız ağrı azaltıcı yöntemlerin en önemlilerindendir (10). Ancak yaşın ve kullanılacak aracın standardize olmaması ve maliyet gibi nedenler birinci basamak hizmetlerde kullanımını sınırlamaktadır.

Anne göğsünü emmenin ise cilt teması, emme ve sütün tadından oluşan üç ayrı bileşenin dikkat dağıtıcı etkisiyle aşı sırasında ağrıyı azalttığı gösterilmiştir. Her geçen gün daha çok benimsenen bir yöntemdir (11). 
Fiziksel yöntemler dokuya masaj, dokunma ya da ovuşturulma sonucu kapı kontrol teorisinde açıklanan şekilde ağrı iletisi azaltır. Bilinen en klasik örnek akupunkturdur. Ciddi bir eğitim gerektiren akupunkturun en önemli dezavantaj1 iğnelerin korkuya neden olmasıdır (12).

Enjeksiyon bölgesine manüel basınç uygulanmanın IM aşı ve immünglobilin yapılan erişkinlerde ağrı algısını azalttığ 1 gösterilmiştir $(13,14)$. Akut romatizmal ateş korunması için benzatil penisilin uygulanan çocuk ve ergenlerde enjeksiyon öncesi manuel bası uygulamanın IM enjeksiyon ağrısını azalttığı bildirilmiştir (15).

Tek bir yöntem kullanmaktansa farklı etki mekanizmasıyla etki eden birden çok yöntemin kombine edilmesinin (multimodal) ağrı yönetiminde daha etkili olduğu bazı çalışmalarda bildirilmiştir $(16,17)$.

\section{Yenidoğan ve Süt Çocuklarında Girişimsel Ağrı ve Non-farmakolojik Yönetimi}

Ağr1 süt çocuğunda hayatta kalmak için önemli bir bulgudur. Subjektiftir ve en iyi yaşayan tanımlar. Sağlık durumunu direk etkileyen kontrol edilmediğinde hayatın bütün alanlarında olumsuz sonuçlar doğuran bir sorundur. Emosyonel, kognitif ve davranışsal kompenentleri de vardır. Ağrı algısı ve etkisi bireyin sosyokültürel düzeyinden de etkilenmektedir. Uygun şekilde tedavi edilmediğinde uzun dönemde ağr1 duyarlılığında, bağışıklıkta, nörofizyolojide ve davranışlarda olumsuz etkileri olduğuna dair kanitlarda mevcuttur (18). Bu nedenle çocuklara bakım veren sağlık çalışanlarının akut ya da kronik ağrının tanınması ve tedavisinde eğitim görmüş olmaları önemlidir.

Süt çocuklarında ağrıyı düşündüren davranış değişiklikleri klinik değerlendirmede kullanılmaktadır. Henüz 20 gestasyon haftasinda immatür olsa bile fonksiyonel ağrı sistemlerinin mevcut olduğu, ağrıyı algılayabildikleri ve doku hasarına cevap verdikleri bilinmektedir. Nosiseptif ağrı sistemi yaşamın ilk yıllarında hızla olgunlaşmakta ancak tam matürasyona adölesan dönemde ulaşmaktadır (19). Doğuma kadar inen inhibitör sistem gelişmemiştir ve asendan yollara kıyasla daha yavaş olgunlaşır (20). Travma sonrası oluşan nosiseptif input (ağrılı uyaran) erişkinlere kıyasla çocuklarda daha yoğundur ve bu şekilde devam eder. Bu durum ağrı yollarında uzamış ya da yoğun sitimülasyon sırasındaki nöronal plastisiteye bağlı olarak sinir hücrelerinde kayıp ya da sinir sisteminde değişikliklere neden olabilmektedir (21, 22).
Bebeklerde tekrarlayan zararsiz stimülasyon refleks eşiğinde düşmeye neden olur bu durum sensitizasyonun temel mekanizmasıdır. (23).

Yenidoğan ve süt çocuklarında analjezik ve sedatif etkili ilaçlara duyarlılık söz konusudur ve bunların gelişmekte olan beyne nörotoksik etkileri gösterilmiştir (24). Hem ağrı hem de bunu gidermek için kullanılan analjezikler nedeniyle sinir hücreleri zarar görmektedir. Bu sebeple ağrı en aza indirilmeli ve olabildiğince az miktarda analjezik kullanılmalıdır. Klinisyenlerin İlaçların farmakokinetik etkileri kadar ilaç dışı tedavi modellerini de bilinmesi oldukça önemlidir. Ne yazık ki pediatrik çalışmalarda ilaç dışı tedaviye yönelik alan ihmal edilmiş ve konuya ilişkin araştırmalar yetersiz kalmıştır (25).

Preterm bebeklerde nosiseptif devre ağrının algilanmasında gerekli olmakla birlikte immatürdür (26). Yenidoğanlarda deride alg1 alanı daha geniştir ve duyusal liflerde doku hasarına duyarlıdır. Spinal kordun düşük eşikli takdil inputları lamina II de akson terminalleri geçici olarak üst üste gelmektedir. Bu durum yenidoğanların zararl1 zararsiz uyaranlar arsinda ayrım yapmasinı zorlaştırır. Bu sebeple 35 gestasyon haftasından küçük bebeklerde tekrarlayan işlemler santral sentizizasyona neden olur. Bu durum çok küçük pretermlerde topuk kanı örneklemesi sırasında EEG kayıtlarında dağınık nöroral burst dalgalarına neden olmaktadır (27). Bu EEG kayıtları pretermlerde radyal glianın kaybı ve serebral korteksin karmaşık yapısına karşılık gelmekte$\operatorname{dir}(28)$.

Yenidoğan bebeklere topuk kanı örneği alınmaS1, aş1 ve sünnet olmak üzere çok sayıda girişimsel ağrılı uygulama yapılmaktadır. Bunlara ek olarak çok küçük pretermlere (24-32. Hafta) yenidoğan yoğun bakım ünitelerinde hayata tutunmalarını sağlayan bakımın bir parçası olarak hızlı beyin gelişimi ve fizyolojik duyarlılı̆̆ın olduğu bu dönemde tekrarlayan ağrılı işlemler uygulanmaktadır (26). Kateter takılması, göğüs tüpü uygulanmas1, entübasyon, lomber ponksiyon ve enjeksiyonlar bunlardan bazılarıdır. Bir çalışmada 32 gestastyon haftasının ya da 1500 gramın altında doğan bebeklere ortalama günde iki ila on invazif işlem uygulandığ (29). Çok küçük pretermlerde ağrılı uyaranların lokazisyonu, ayırt edilmesi ve inen inhibitör kontrolü azalmış tekrarlayan ağrılı uyaranlara duyarlılığ 1 artmıştır. Yenidoğan yoğun bakım (YYB) ünitelerindeki bu bebeklerin ağrısının fark edilmesi ve yönetimi oldukça önemlidir. Tipik olarak preterm bebekler ağrılı uyaranlara belirgin davranışsal tepki göstermezler ancak bu ağrıya yüksek tolerans olarak yorumlanmamalidir. 
İyi yönetilmeyen ağrılar yenidoğanda kalp hızı ve kan basıncinda artış, otonomik tonusta farklilik, arteriyal oksijen saturasyonunda düșme ve cilt kan akımında azalma gibi akut etkilerin yanı sıra ağrı duyarlılığında değişiklikler gibi uzun dönem etkiler bırakmaktadır. Ağrılı uyaranın, spinal kordonda ağrının işlendiği nöronal devrede kalıcı değişiklikler yaptığı bir çalışmada gösterilmiştir (30). Doğumdan hemen sonra topikal anestezi uygulanan ve uygulanmadan Sünnet edilenler kıyaslandığında anestezi olmaksızın işlem yapılan bebeklerin 4+ aylarda yapılan aşılarda daha fazla tepki gösterdikleri bildirilmiştir (31).

\section{Pediatrik Ağrının Etiyolojisi}

Çocuklarda akut ağrının girișimsel işlemlerden kaynaklanan başlıca nedenleri cerrahi işlemler, travma ve akut hastalıklardır. Her birinin kendine özgü sebebi olmakla birlikte bazı genel faktörler önemlidir. Bunlar sırasıyla hastaya bakan personelin eğitimi, ağrının ölçümü, öngörülmesi, telkin edilmesi ve bu sürece ailelerin dâhil edilmesidir.

\section{Süt Çocuğunun Ağrısı Ve Refleks Davranışı}

Pereterm ve term yenidoğanlar nosiseptif reflekslere sahiptir. Doku hasarı yapan uyaranlar karşısında alt ekstremiteyi çekme ve fleksör kas aktivitesi gibi uzun süren fleksiyon refleks gösterirler (32). Gestasyon haftası arttıkça bu süre kısalır. Bu koruyucu refleksler etkilenen bölgeyi hasardan korur.

\section{Ağrılı İşlemlere Çok Küçük Pretermelerin Cevabı \\ Küçük Pretermlerde Tekrarlayan Ağrıyla İlişkili Stres}

Stres hormonları vücut ve beyinde genlerin transkripsiyonunu düzenleyen glikokortikoidlerdir. Fizyolojik olarak immatür yenidoğanlarda hipotalamus-hipofiz-adrenal aksin uzamış aktivasyonu hormonel (büyüme hormonu, glikokortikoid), fizyolojik (metabolik, immün) ve davranışsal (anksiyete, depresyon) sistemlerde uzun süreli değişikliklere neden olur. Çok küçük pretermlerde, kortizol düzeyi hastanede yattığ 1 süre boyunca beklenenden düşüktür. $\mathrm{Bu}$ durum immatür adrenal korteks ve fizyolojik olarak immatür yenidoğanların kaynaklarının tükenmesini yansıtmaktadır. YYB'deki çok ağrılı işlemlerin uygulanması stres hormon sisteminin yeniden programlanmasina yol açar. Çok düşük gestasyon haftalı bebeklerde üçüncü ayda düşük olan bazal kortizol seviyesi 8-18. aylar civarında göreceli yüksek düzeylere ulaşmaktadır. Stres cevabındaki uzun süren değişiklikler devam eden streslerin etkisine duyarlıl1k gösteren hipokampus ve prefrontal korteks gibi glikokortikoid reseptörlerden zengin bölgelere bağlı gibi gözükmektedir (33).

\section{Neonatal Ağrı Stresi Ve Beyinin Gelişimi}

Prematür beyinde hasara en duyarlı hücre popülasyonları subplate nöronlar ve preoligodendrositlerdir. Tekrarlayan girişimsel ağrılar glutamatın aşırı salınımı ve kalsiyumun nöronların içine aşırı girmesi sonucunda subplate nöronlarda apopitosis ve eksitotoksisiteye yol açabilir (28). Neonatal ağrı stresi miyelin üreten aksonlara dönüşmeden önce aksonları kaplayan preoligodendrositler üzerine de etki eder. $\mathrm{Bu}$ hücrelerin immatüritesi onları özellikle oksijen ve nitrojen türlerine ve mikroglialardan salınan sitokinlere duyarlı hale getirir. Girişimsel işlem ağrısı hem oksidatif stresi hem de inflamatuar reaksiyonları indükleyerek pre-miyelizan hücrelerin gelişimini duraksatabilir $(34,35)$. Küçük pretermlerde girişimsel ağrı ve stresin term yaşıtlarına göre anormal beyin gelişimine neden olduğu yakın zamandaki bir çalışmada gösterilmiştir (36). Bu bulgu bir başka çalışmada tekrarlayan enjeksiyon ve enflamasyon ağrısinin neonatal kobay beyinlerinde apopitozise yol açtığının bildirilmesiyle de desteklenmektedir (37). Yenidoğanla ilişikli stres ve beyin gelişiminin etkisi yaşamın erken döneminden ötesine kadar uzanmaktadır. Yapılan bir çalışmada YYB'de yüksek oranda cildi delici işlemler yapılan bebeklerin yedi yaşına geldiklerinde 66 çocuğun 21 'inde kortikal gri maddenin daha ince olduğu ve bunun en belirgin şekilde frontal ve pariyetal lobları etkilediği gösterilmiştir (38). Neonatal dönemdeki girişimsel ağrı ve stresin uzun dönemde nöronal yapı ve fonksiyonu üzerine etkili olduğu görülmektedir. Neonatal ağrı stresi artıkça çocukların kognitif ve motor fonksiyonu azaltmakta anksiyete ve depresyonu artmaktadır. Ancak YYB ünitelerindeki pretermlerin beyin gelişimi birçok faktörden etkilenmekte bunu sadece ağrıyla ilişkilendirmek mümkün olamamaktadır (39). Kümülatif yenidoğan ağrı stresi okul çağında spontan beyin aktivitelerinde değişikliklere neden olabilir. Bunun nedeni girişimsel ağrının neonatal beyin gelişimine etki etmesidir (40).

\section{Aşı Enjeksiyonu Ağrısı}

Aşı enjeksiyonları süt çocuğu ve küçük çocuklarda ciddi stres kaynağıdır (41). Bu durum klinisyenler ve ailelerde ağrı endişesi, aşının ertelenmesi ya da yapılmamasina neden olmaktadır. Çocuklarda aşılama sırasındaki olumsuz tecrübeler hayat boyu iğne fobisi oluşturarak tedavilerde uyumsuzluk nedeni olabilir (42) 
Aşı sırasındaki ağrının dikkate alınmaması ebeveynlerin sağlığa ilişkin tutumlarına negatif yönde etki eden faktörlerden birisidir. Bu aşının geciktirilmesine ya da yaptırılmamasına neden olmaktadır. İğneden kaynaklı enjeksiyon ağrıs1 aşılama programlarını sekteye uğratarak aşı ile önlenmesi mümkün hastalıklarda salgınlara neden olabilir. Yakın zamandaki bir çalıșmada aşılamaya ilişkin tereddüttün giderilmesi için aşı ağrısının azaltılmasının önemli bir strateji olduğu bildirilmiştir (43).

Amerika ve Kanada'da aşı yapılan çocukların ebeveynlerinin yer aldığ 1 araştırmada yaklaşık \%24-40'nın aşı ağrısından endişe duyduğunu, $\% 85$ 'nin ağrının azaltılmasının sağlık çalıșanlarının sorumluluğunda olduğunu düşündükleri, \%95'nin de aşı yapılırken ağrının nasıl azaltılacağını öğrenmek istedikleri bildirmiştir $(44,45)$.

Uygun teknik, uygun kalınlık ve uzunluktaki iğneyle yapılan aşılarda aşının bileşimine bağlı olarak değişik düzeyde ağrı meydana gelmektedir. Birden çok aşı aynı zamanda uygulandığında akıtma sırası ağrının düzeyini etkilemektedir. İlk olarak en ağrılı enjeksiyonun yapılması kümülatif ağrıda artışa neden olur.

Dünya Sağlık Örgütünün aşı ağrısını azaltmaya yönelik 2015 yılındaki yayınında özetle şunlar önerilmiştir (46); tüm yaş grupları için;

1. Aş1 uygulayan personelin güven azaltıcı ve anksiyete artırıcı dil kullanmaktan kaçınması

2. Yaşa uygun olarak örneğin süt çocuğu ve küçük çocuklarda ebeveyni tarafından tutularak uygun pozisyon verilmesi

3. İğneyle teması arttıracağı, iğnenin hareket etmesine neden olacağ 1 ve bunların ağrının artmasına yol açacağından intramüsküler enjeksiyonlarda aspirasyon yapılmamas1

4. Birden çok aşının yapıldığ 1 durumlarda aş1lama sırasının en az ağrılıdan en çok ağrılıya doğru yapılması önerilmiştir.

Yine bu raporda süt çocuğu ve küçük çocuklar için şu önerilerde bulunulmuştur;

1. Çocuğun ebeveyninin aşı boyunca hazır bulunmas1

2. Üç yaş altındaki çocukların ebeveyni tarafında tutulması, üç yaş üstündekilerde ise ebeveynin kucağında oturtulması

3. Mümkün olduğunca aşı sırasında ve aşıdan hemen önce emzirilmesi, oral aşılamaların enjeksiyonlardan önce uygulanması oral aşılardan sonra bebeğin emzirilmesi

4. Altı yaşından küçük çocuklarda ise oyuncak, video, müzik gibi dikkat dağıtıcı yöntemlerin kullanılması önerilmektedir.

Aşıya bağlı enjeksiyon ağrısını azaltmak için sükroz, topikal anestezi, emzirme gibi birçok yöntem mevcuttur. Ama süt çocuklarının çoğunluğunda bu yöntemler kullanılmaksızın aşılar yapılmaktadır. Ebeveynler ise aşıya bağlı ağriyı azaltmak istemekle birlikte bunun nasıl yapılacağı konusunda yeterince bilgi sahibi değildirler (47). Her ne kadar topikal anestezikler etkili olsa bile ulusal aşı programlarında topikal anesteziklerin kullanılması yüksek maliyet, işlemin uzaması gibi nedenlerle önerilmemektedir.

\section{İğne Boyutu Ve Enjeksiyon Hızının Aşı En- jeksiyon Ağrısına Etkisi}

Cochrane veri tabanında çoğunlukla 2-6 ay arasındaki süt çocuklarının incelendiği üç çalışmanın meta analizinde aşı için kullanılan 23-25 gauge kalınlığında ve 25-16 mm uzunluğunda iğneler karşılaştırıldığında şu sonuçlara ulaşılmıştır;

1.Kızarıklık ve şişme gibi reaksiyonların uzun iğnelerde daha az görüldüğü orta düzeyde kanit1

2. Aşı ağrısının kanıtı zayıf olmakla birlikte kalin iğnede daha az olduğu

3. Geniş ve uzun olan iğnelerde ağlama süresinin daha az sürdüğünün orta düzeyde kanıtı

4. Buna karşın ağrı ve ağlamanın pratik önemi olmayacak kadar az olduğu bildirilmiştir (48).

İntramüsküler (IM) aşılar günümüzde sık uygulanan enjeksiyonlardır. Intramüsküler enjeksiyonların hangi boy iğne ve hangi açıyla yapılacağına dair kanıta dayalı öneriler olmakla birlikte enjeksiyon hızına ilişkin kılavuzlara etki edecek çok az kanıt bulunmaktadır (49). 2-6 ay arasındaki bebeklerde enjeksiyon hız1nın aşı ağrısına etkisinin değerlendirildiği randomize çalışmada bebekler hızlı $(2-4 \mathrm{ml} / \mathrm{sn})$ ve yavaş enjeksyon $(5-10 \mathrm{ml} / \mathrm{sn})$ olmak üzere iki gruba ayrılmıştır. Karma aşısı hızlı enjeksiyonla yapılanlarda ağrının daha az hissedildiği bildirilmiştir. Aşı enjeksiyonunun hızlı yapılması bu çalışmada ağrının azaldığını göstermekle birlikte hızlı enjeksiyonun uygulanabilirliği ve pratik olması açısından klinikte yapılması önerilmektedir (50). 


\section{Ağrı Yönetimi}

Ağrı yönetiminde farmakolojik ve non-farmakolojik birçok yöntem kullanılmaktadır. Uygulanan farmakolojik yöntemlerden analjezik, anastetik ve sedatiflerin uzun dönem yan etkileri olabilmektedir. Bu nedenle cerrahi dışı ağrı yönetiminde pretermler için yan etkileri kontrol altına alabilmek amaciyla kilavuzlar düzenlenmiştir (8). Sükroz, kıvırarak tutmak, kanguru bakımı, emzik vermek, emzirme, kundaklama kullanılan non-farmakolojik yöntemlerdendir (51). Bunlar arasında sükroz en yaygın önerilen ve YYB'larda en çok kullanılan yöntemdir. Cochrane veri tabanında üç yaş altı çocuk ve süt çocuklarında girişimsel işlem ağrılarının ilaç dışı tedavisine yönelik uygulamalarda çok fark11 yöntemlerin kullanılabileceği bildirilmiștir. En yerleşik kanıtlara göre emzik, kundaklama, facilitated tucking ve sallayarak tutmanın sik kullanıldığ bu alandaki yöntemlerin güvenirliliği artırmak için daha fazla çalışma yapılması gerektiği, süt çocuğu akut ağrısında mevcut literatürde önemli bir açık olduğunu bildirilmiştir. Bu meta analizde 63 çalışma yer almış olup 32 si topuk kanı örneği alma,12 si ise iğne ağrısından kaynaklanan çalışmalardan oluşmaktadır (52). Özellikle YYB da ağrı yönetiminde optimal yöntemlerin bulunması için daha fazla çalışmalar yapılması ve bakımı üstelenen sağlık çalışanlarının bu konuda daha duyarlı olması bebeklerin beyin ve davranışsal gelişimine faydalı olacaktır.

Emlanın kullanıldı̆̆ı aşı uygulamalarının plaseboyla karşılaştırıldığ 1 bir derlemede, 2-6 ay arasındaki çocuklarda emlanın plaseboya kıyasla ağlama ve ağrıya bağlı davranış skorlarında anlamlı pozitif etkisi olduğu ve herhangi bir önemli zararı olmadığı bildirilmiştir (53). Buna karşın süt çocuklarında ağrı ve stresi azaltmaya yönelik önerilen emzirme, ten tene temas, glükoz /sükroz solüsyonu ve kundaklama gibi yöntemler emlaya sinerjik etki gösterebilmektedir. Bir çalışmada emlayla birlikte emzirmenin aşı ağrısında tek başına emladan daha etkin olduğu bildirilmiş olup kombinasyon teknikler rutin çocukluk çağı aşılarında tavsiye edilmektedir (54).

\section{Ağrı Yönetiminde Multimodal Yaklaşım}

Tek bir yöntem kullanmaktansa farklı etki mekanizmasıyla etki eden birden çok yöntemin kombine edilmesinin (multimodal) ağrı yönetiminde daha etkili olduğu bazı çalışmalarda bildirilmiştir $(16,17)$. Aşı yapilan bebekler için henüz optimal bir multimodal yaklaşım yöntemi geliştirilememiştir. Bu durum çok az sayıda ve farklı teknikleri içeren çalışmaların mevcut olmasından kaynaklanmaktadır. Özellikle süt çocuklarının birinci basmaktaki rutin aşılamasinda kolayca uygulanabilen ve maliyetsiz ilaç dış1 multimodal yaklaşım yönteminin geliştirilebilmesi için kontrollü çalışmalara gereksinim vardir.

\section{Ağrı Yönetiminde Non-Farmakolojik Yön- temler}

\section{Kanguru Bakımı}

Bebeğin kanguru pozisyonuna benzer şekilde eli ya da ayağının tespit edilerek kendi vücudunu kontrol etme şansı verilen pozisyona facilitated tucking denir. Sadece bezi bağlı olan çocuğun annesinin çıplak göğsüne temas etmesiyle sağlanan bu yöntem, kanguru annelerin yavrularına bakımındaki benzerliğinden dolayı kanguru bakımı olarak adlandırılmıştır. Ağrıyı azaltmak için topuk kanı alınması ve aspirasyon sirasında kullanılır. Kanguru bakımı cilt cilde temas olarak tanımlanır ve sik olarak doğumdan hemen sonra uygulanır. Yaygın olarak özellikle gelişmekte olan ülkelerde preterm bebeklerde morbiteyi azaltarak onların sıcaklığını korur. Gelişmiş ülkelerdeki sağlık çalışanları kanguru bakımının öneminin farkında değildir. Topuk kanı alınması sırasında kanguru bakımı preterm bebeklerin ağrı skorlarını azaltarak ağlama sürelerini kısaltmıştır. Ancak yöntemin mekanizması iyi bilinmemektedir. Annenin kalp atışın duyulması daha az maternal stres gibi nedenlerle açıklanmaktadır. Stabil ve 1000 gramın üzerindeki pretermlerde uygulanmaktadır. İlginçtir ki bu sırada kardiyo respiratuvar olumsuzluklar azalmaktadır. Hastanede kaldığ1 sürede, pretermlerin anneyle etkileşimi beyaz madde matürasyonunu sağlar ve ağrıya bağlı davranışların negatif etkisini azaltır (55). Buna karşın tekrarlayan ağrilı işlemlerde oral sükroz kadar ağrıyı azaltmada etkili olmayabilir (56).

Aşı sırasında bebeği tutmanın ağrıyı azaltmaya etkisi çok az bilinmektedir. Çoğu klinikte aşı uygulamaları bebek muayene masasına yatırılarak yapılır. Ten temasının ağrı azaltıcı etkisi yenidoğanlarda gösterilmiş ayrıca gestasyon haftasına göre ağrı cevapları çok sayıda çalışmayla incelenmiştir. Yenidoğan dönemi sonras1 ise süt çocuklarının işlem ağrıları yeterince araştırmacıların ilgisini çekmemiştir (57).

YYB'da topuk kanı alma, kan alma ve enjeksiyonlar esnasında ağrıyı azaltmak için kullanilan analjezik ilaçlar sorunlara yol açtığından alternatif olarak kullanılan kanguru bakımının ağrıyı azalttığı düşünülmektedir. Kanguru bakımının ağrıyı azaltığına yönelik çok az kuvvetli kanıt gösterilmiştir ancak güvenilirdir. 
On dokuz çalışma incelendiğinde fizik ve davranışsal işaretlerin ağrı skorlamasının sonuçları kanguru bakımını desteklemektedir. Tek başına ağrının kalp hızı gibi fiziksel göstergelerinde bir farklılık oluşturmayan kanguru bakımının Cochrane veritabanında faydasının çok olmadığ ama etkili olduğu bildirilmiştir (58).

\section{Taktil Uyarı}

Taktil uyarı herhangi bir ayrıntılı eğitim gerektirmeyen, ücretsiz, kolay uygulanabilir bir yöntemdir. $\mathrm{Bu}$ klinisyenin yanı sira ebeveynler tarafindan da kolaylıkla uygulanabilir. Taktil uyaranın etki mekanizması kapı kontrol teorisiyle açıklanmaktadır. Spinal kordun arka boynuzunda ağrıyı hızlandıran ya da yavaşlatan iletisini beyne taşıyan bir geçişin olduğu farz edilmektedir $(59,60)$. Kisaca özetlersek A-delta, A-beta ve C liflerinden oluşan primer afferent nöronlar derideki duyusal sinyalleri spinal kord aracılığıyla beyne taşımaktadır. A-delta ve $\mathrm{C}$ lifleri ağrı inputunu taşırken A-beta lifleri dokunma duyusunu iletmektedir. A-beta lifleri C ve A-delta liflerinden daha hızlı ileti taşır. Deri bası uygulayarak ya da ovularak uyarıldığında A-beta lifleride uyarılır. A-beta lifferi diğer lifferle aynı anda uyarılırsa A-betanın sinyalleri arka boynuza daha hızlı ulaştığından diğer liflerin sinyallerinin geçişini inhibe eder diğer bir ifadeyle kapıyı kapatır. Buda beyne daha az ağrı sinyalinin ulaşmasına sebep olur. Tek bir sinirle derinin inervasyonun sağlandığı cilt alanına dermatom denir. Dermatom sinırları kişiden kişiye değişmekte, alanları birbiri üzerine geçebilmektedir. Dermatomdan gelen sinir lifleri spinal segmentlere korlateral dallar verir. Böylece taktil ve ağrı uyarıları birbirine yakın olduğunda spinal segmentle dermatomdan gelen uyarılar birbirinin üstüne geçer. $\mathrm{Bu}$ durum aynı dermatom olmasa bile söz konusu olabilmektedir (61).

Çocuk ve erişkinlerdeki enjeksiyonlarda Taktil uyarının analjezik etkisi kanıtlanmış (13, 14, 62), çocukluk çağı aşılamalarında da uygulama önerisi kılavuzlarda tavsiye edilmiştir (9). Süt çocuklarında ise aşılamada taktil uyarı yeterli çalışmayla desteklenmediğinden dolayı rutin uygulamada yer almamıştır.

Yakın zamanda yapılan süt çocuklarının aşılamasında taktil uyarının ebeveyn ya da klinisyen tarafindan diğer ağrı kesici yöntemlerle birlikte kullanıldığında ağnıyı azaltıcı etkisi olmadığ bildirilmiştir. Ancak bu çalışmalarda izole olarak taktil uyarının kullanılmaması diğer etkili yöntemlerle bir arada uygulanması nedeniyle etkinliğinin maskelenmiş olabileceği de düşünülmüştür $(63,47)$.
Enjeksiyon ya da iğne batması sırasında taktil uyarının (dokunsal) ağrıya etkisi az sayıda çalışmayla incelenmiştir. Ağırlıklı olarak erişkinlerde yapılan çalışmalarda IM ve subcutan enjeksiyon sırasında baskı ya da taktil uyarı yapılmış ve bu yöntemin etkin olduğu bildirilmiştir $(62,64)$. Çocuklarda ise taktil uyarının etkisine ilişkin yapılan çalışmalar tartışmalı sonuçlar ortaya koymuştur. Topuk kanı örneği alınması sırasında pretermlerle yapılan çalışmada (65) ve 4-6 yaş arası aşı uygulanan çocuklarda taktil uyarının etkili olduğu bildirilmiştir. Bu iki çalışmada ağrılı uyaranda farklılık göstermektedir. Aş1 enjeksiyonunda derinin delinmesinin ağriya neden olmasınn yanı sıra enjekte edilen aşının hacmide gerilime bağlı ağrı oluşturmakta, sıvının fizyokimyasal özellikleri de ağrıya neden olmaktadır. Diğer yandan topuk kanı örneklemesinde küçük bir cilt kesisi meydana gelmekte ve topuk kan alınması için sıkılmaktadır. Ancak bu çalışmalar çalışmanın kör olmaması, aynı gün yapılan enjeksiyonlarda yöntemin etkinliğinin değerlendirilmesi ya da yeterince randomizasyonun yapılmamasi gibi nedenlerden dolayı sonuçlardan kesin çıkarımlar yapilmasina olanak vermemektedir. $\mathrm{Bu}$ sebeple özellikle aşılanan süt çocuklarında taktil uyarının etkinliğine yönelik randomize kontrollü çalışmalar yapılmış fakat çalışma sonuçlarında ağrıya etkisinin olmadığı bildirilmiştir (63, 47). Taktil uyarının oral sükroz, bebeği tutmak ya da aspire etmeksizin hızlı enjeksiyon yapılması gibi ağrı kontrolunde etkin olmadığının gösterlmesi ne rağmen çoğu olguda ebeveynler taktil uyarı yöntemini kolay bulmuş ve yaklaşık yarısı bebeklerinin taktil uyarıdan istifade ettiklerini düşünmüşlerdir. Hiç bir yan etkisi olmayan bu yönteminin rutin kullanımı önerilmese bile ebeveynler bunu talep ettiğinde buna engel olmayı gerektirecek herhangi bir kanit yoktur (63).

$\mathrm{Bu}$ az sayıdaki çaışmanın 1şı̆̆ında aşı ağrısında daha küçük çocuklarda yeterince kanıt olmamasından dolayı 4 yaş ve üzerinde taktil uyarı aşı kılavuzunda önerilmiştir (9). Taktil uyarı kısa bir eğitimle pratiğe geçirebilecek maliyeti olmayn bir girişimdir.

\section{Anne Sütü}

Sağılmış anne sütünün analjezik etkisiyle, disakkarit olan laktozun oral tat duyusuna etkisinin ve endojen opiad yollarının birbiriyle ilişkili olduğu düşünülmektedir. Bu tat duyusu algisı prematür bebeklerde bile oldukça iyi gelişmiştir (66) . Triptofan içeren anne sütü bu sayede betaendorfinlerin artışını sağlayarak ağrryı azaltmaktadır $(67,68)$. Anne sütü doğal kolaylıkla edilir, güvenilirdir. 
Cochrane veri tabanında emzirme ve anne sütünün topuk kanı örneği alma ve damar yolu açılması gibi minör ağrılı işlemlere etkisini inceleyen çalışmaların meta analizinde yenidoğanlarda etkili olduğu bildirilmiştir. Buna karşın şırıngayla verilen anne sütünün emzirme kadar etkili olmadığı da rapor edilmiştir (69). Daha ağrılı bir girişim olan retinopati muayenesinde sağılmıș anne sütü verilen yenidoğanlarda ağrı skorlarının anlamlı olarak azaldığ 1 bildirilmiştir (70).

\section{Sükroz}

Ağriyı azaltmada emzik verme ve tatland1rıcılar endojen endorfinlerin salınımına neden olmakla birlikte tam mekanizmaları bilinmemektedir. Emzikle kıyaslandığında tatland1rıcılar ağrıya karşı oluşan antinöseptif cevabı güçlendirir (71). Sükroz ve glikoz her ikisi de emziğin etkisini artırır ve topuk kanı alınması gibi işlemlerde ağrı skorunu düşürür, ağlama süresini kısaltır (56). Pretermlerin minör işlemleri için sükroz en sık kullanılan uygulamadır. Her ne kadar oral sükroz davranıșsal cevaplarda azalma sağlasa da EGG cevabında ağrıyı azalmakta etkisi olmamaktadır (51). Tatland1rıc1 solüsyonların mekanizmaları oral yoldan kontrol edilen endojen opiadların salınımını ile ilişkilendirilir. Bu mekanizma bir yaşından büyük süt çocuklarında olduğu gibi çocuklarda da çalışılabilir. Bunla ilgili kanıtlar olmakla beraber sükrozun girişimsel ağrılara etkisine ilişkin tartışmalı sonuçlar bildirilmiştir. Sükrozun etkisinin yenidoğanlara kıyasla daha az olmakla birlikte 12 aya kadar devam ettiği kabul edilmektedir (72). Sükroz prematür retinopati taramas1, oral gastrik sonda takılması ve topuk kanı örneği alınması gibi ağrılı uyaranlarda ağrıyı azalmaktadır. Bunun yanında tekrarlayan kullanımı uzun dönemde olumsuz sonuçlar doğurabilmektedir (56). Topuk kanı örneği alınması sirasinda anne sütü ve anneyle ten temasindan herhangi birinin tek başına uygulanmasından daha fazla ağriyı azalttığ gösterilmiştir (73). Ülkemizde yapılan 16-19 ayda rutin aşılamada sükrozun yüksek konsntrasyonda (\%75) kullanıldığında ağrıyı azaltmada daha etkili olmasinın yanı sira standart konsantrasyonda da (\%25) etki ettiği gösterilmiştir (74). Küçük süt çocuklarına kıyasla tatlandırıcıya duyarlılık yaş ilerledikçe azalmakta ve ancak daha yüksek konsantrasyonda etkisi daha iyi olmaktadır. Emme refleksi kaybolduktan sonra sükrozun sakinleștirme etkisi özgün olmayabilir. Bu analjezik etki tek başına sükroz değil suyunda etkisiyle açıklanabilir. Sükroz ağrilı uyarandan iki dakika önce uygulandığında maksimum etki ile dört dakika boyunca etki göstermektedir. Sünnet ve oftalmolojik muayene gibi uzun süren işlemlerde analjezik etkisinin devamı çok sayıda doz uygulanarak sağlanabilir. İnsan yenidoğanlarında mekanizması çok iyi anlaşılmamakla birlikte hayvan çalışmalarında sükrozun analjezik etkisi tat duyusunun aracılığıyla opiad, endorfin, dopamin ve asetil kolin yollarının cevabına bağlı olduğu düşünülmektedir. Sükroz emzik, kundaklama gibi diğer ilaç dışı yöntemlerle birlikte kullanıldığında özellikle oftalmolojik muayene ve aşı uygulamalarında katkı sağlamaktadır. Sükrozun işlemsel ağrılarda ağrı azaltıcı etkisi kanıtları güçlü olmakla birlikte küçük bir randomize kontrol çalışmada topuk kan örneği alınmasına bağli term bebeklerde su ile oral sükroz arasındaki etkiyi inceleyen çalışmada EGG 'de noseptif beyin aktivitesi ya da EMG'de spinal noseptif yanitında fark bulunamamıștır. Ancak bu çalışmada da sükroz alan bebeklerin ağrı skorları azalmış ve çalışmanın metodolojisi çalışmadan sonuç çıkarılmasını s1nirlamaktadır $(75,76)$.

\section{Dikkat Dağıtma}

Dikkat dağıtma, oyalama teknikleri çocuklarda ağrılı girişimlerle başa çıkmak için sıklılkla kullanılan ağrı yönetim tekniklerinden biriridir. 0-3 yaş grubundaki çocuklarla yapılan aşı uygulaması sırasında dikkat dağıtmaya yönelik yapılan çalışmaların metaanalizi sonucunda zayıf ama yeterli kanıt sunarak oyuncak ya da video gibi yöntemlerle dikkat dağıtmanın ağrı azaltıcı etkisi bildirilmiştir. Video yöntemi uygulanabilirliği sınırlı olanakları olan merkezlerde sorun olmakla birlikte oyuncak ya da araba anahtarı gibi materyallerin kullanılması ucuz olmakla birlikte işlevsel olabilmektedir (52).

\section{SONUÇ}

Ağrı sağl1k durumuna etki eden kontrol edilmediğinde hayatın bütününe olumsuz sonuçlar getiren bir sorundur. Çocuklar doğumdan itibaren bir dizi ağrılı uygulamalara maruz kalırlar (77). Sağlıklı çocuklara 2 ila 15 ay arasinda beş defada her birinde üç adete ulaşabilen ve okul öncesine kadar devam eden aşı enjeksiyonları yapılmaktadır. Bu nedenle çocuklarda ağr1 sitimülasyonunun azaltılması ve tedavisi oldukça önemlidir (24).

Girişimsel uygulamalardan kaynaklanan ağn1larda kuvvetli bir ağrı öngörüsü mevcuttur. İlk uygulamada ağrının kontrol edilememesi sonraki uygulamalarda stresin ve hissedilen ağr düzeyinin artmasina neden olmaktadır (78). Özellikle enjeksiyonlar süt çocuğu ve küçük çocuklarda ciddi stres kaynağıdır (Jacobson ve ark., 2001). Bu durum klinisyenler ve ailelerde ağrı endişesi, aşının ertelenmesi ya da 
yapılmamasına neden olmaktadır. Çocuklarda aşılama sırasındaki olumsuz tecrübeler hayat boyu iğne fobisi oluşturarak tedavilerde uyumsuzluk nedeni olabilir (42). İyi yönetilmeyen ağrılar yeni doğanda kalp hızı ve kan basıncında artış, otonomik tonusta farklılık, arteriyal oksijen saturasyonunda düşme ve cilt kan akımında azalma gibi akut etkilerin yanı sıra ağrı duyarlılığında değişiklikler gibi uzun dönem etkiler bırakmaktadır. Tüm bu sebeplerden dolayı yenidoğan ve süt çocuklarında girişimsel ağrının yönetimi oldukça önemlidir.

Ağrı yönetimine ilişkin çok farklı seçenek olmasına rağmen etkin bir şekilde kullanılmamaktadır. Klinisyenler maliyet, yan etki ve zaman gerektirmesi nedeniyle farmakolojik yöntemleri tercih etmemektedirler. Kanguru bakımı, işlem sırasında çocuğun anne kucağında olmas1, sükroz, emzik vermek, emzirme, taktil uyarı ve dikkat dağıtma kullanılan non-farmakolojik yöntemlerdendir (79).

Kanguru bakımı cilt cilde temas olarak tanımlanır (55). Yenidoğan döneminde 19 çalışmanın incelendiği cochrane metaanalizinde kanguru bakımının ağrı üzerine olumlu etkisi olduğu bildirilmiştir (58). İşlem sırasnda anne kucağında olmak çocuğu sakinleştirerek ağrıya yönetimine olumlu etki eder. Özellikle aşı uygulanan çocuklarda bebeğin anne kucağında olmasının etkinliği çalışmalarla da desteklenirse aşının sedyede yapıldığı rutin uygulama değişecektir. Anne göğsünü emme sırasında bebeğin anneyle ten temas1, emme ve sütün tadından oluşan üç ayrı bileșenin dikkat dağıtıcı etkisi ağrı skoruna olumlu etki eder. Anne sütü ile beslenme özellikle yenidoğanda ağrılı girişimler esnasında etkili bir ağrı azaltıcı yöntemdir. Minör girişimsel işlemler sırasında emzirme yönteminin kullanıldığ ağr1 skorlarını düșürdüğü ve ağlama sürelerini kısalttı̆̆ı bildirilmiş ve anne sütünü şırıngayla vermenin anne göğsünü emmek kadar etkili olmadığ 1 da saptanmıştır (69).

Takdil uyarıların klinikte kolay uygulanabilir ve maliyet içermemesi nedeniyle farklı klinik durumlarda süt çocuklarında etkinliğinin çalışmalarla da incelenmesi, etkin olduğu durumlar varsa belirlenerek klinik pratiğe geçirilmesi gereklidir.

Çeşitli araç gerektiren dikkat dağıtma teknikleri kullanılarak çok sayıda çalışma yapılmış ve etkili oldukları bildirilmiştir (10). Ancak araç ihtiyacı ve çocuğun yaşına uygun bu araçların çeşitlilik gerektirmesinin yanı sıra maliyet ve eğitim gibi faktörler bu tekniklerin yaygın kullanımını sınırlandırır.
Tek bir yöntem kullanmak yerine farklı etki mekanizmasıyla etki eden birden çok yöntemin kombine edilmesinin (multimodal) ağrı yönetiminde daha etkili olduğu bazı çalışmalarda bildirilmiştir $(16,17)$.

Ağr1 yönetiminde optimal yöntemlerin bulunması için daha fazla çalışmalar yapılması ve bakımı üstelenen sağlık çalışanlarının bu konuda daha duyarlı olması bebeklerin beyin ve davranışsal gelişimine faydalı olacaktır. Çocuklarda ağrının ileriki zaman etkilerinin de hayatlarını olumsuz etkileyeceği unutulmamalı büyük travmalar yaratan girişimsel işlem ağrılarının yönetimine gereken hassasiyet gösterilmeli bu konuda sağlik profesyonelleri tarafından kılavuzlar oluşturulmalıdır.

\section{KAYNAKLAR}

1. Aydın ON. Ă̆rl ve ăgrt mekanizmalarına güncel bakış. Adnan Menderes Universitesi Tip Fakültesi Dergisi. 2002; 3(2): $37-48$.

2. Melzack R, Wall P. Pain mechanism: a new theory. Pain Clinic. 1994; 7: 57-72.

3. Coghill RC, McHaffie JG, Yen YF. Neural correlates of interindividual differences in the subjective experience of pain. Proc Natl Acad Sci U S A. 2003; 100: 8538-42.

4. Puchalski M, Hummel P. The reality of neonatal pain. Advances in Neonatal Care. 2002; 2(5) 233-47.

5. Uyar M. Çocukta ağrl ve tedavisi. Turkiye Klinikleri J Int Med Sci. 2006; 2(5) 36- 47.

6. Goodenough B, Kampel L, Champion GD, Laubreaux L, Nicholas MK, Ziegler JB, McInerney M. An investigation of the placebo effect and age related factors in the report of needle pain from venipuncture in children. Pain. 1997; 72(3):383-91.

7. Taddio A, Katz J. The effects of early pain experience in neonates on pain responses in infancy and childhood. Paediatr Drugs. 2005; 7,245-57.

8. Batton DG, Barrington KJ, Wallman C. Prevention and management of pain in the neonate: an update. Pediatrics. 2006; 118:2231-41.

9. Taddio A, Appleton M, Bortolussi R, Chambers C, Dubey $V$, Halperin S, Hanrahan A, Ipp M, Lockett D, MacDonald N, Midmer D, Mousmanis P, Palda V, Pielak K, Riddell RP, Rieder $M$, Scott J, Shah V. Reducing the pain of childhood vaccination: an evidence-based clinical practice guideline CMAJ. 2010 December 14;182(18): 843-55.

10. Schechter NL, Zempsky WT, Cohen LL, McGrath PJ, McMurtry CM, Bright NS. Pain reduction during pediatric immunizations: evidence-based review and recommendations. Pediatrics. 2007;119(5):e1184-98.

11. Tansky C, Lindberg EC. Breastfeeding as a pain intervention when immunizing infants. Journal for Nurse Practitioners. 2010;6(4):287-95.

12. Zeltzer L, Schlank CB. Conquering Your Child's Chronic Pain, Harper Resource. 2005, New York.

13. Barnhill BJ, Holbert MD, Jackson NM, Erickson RS. (1996). Using pressure to decrease the pain of intramuscular injections. J Pain Symptom Manage. 1996; 12(1):52-8. 
14. Chung JW, Ng WM, Wong TK. An experimental study on the use of manual pressure to reduce pain in intramuscular injections. J Clin Nurs. 2002; 11(4):457-61.

15. Yavuz DE, Karabacak U, Yavuz T, Ayhan Yİ. Applying manual pressure prior to benzathine penicillin injection for rheumatic fever prophylaxis reduces pain in children. Pain Manag Nurs. 2015;16 (3):328-35.

16. Shah V, Taddio A, Rieder MJ for the HELPING KIDS Team. Effectiveness and tolerability of pharmacologic and combined interventions for reducing injection pain during routine childhood iomunizations: Systematic review and metaanalyses. Clin Ther. 2009;31(B):104-51.

17. Arnstein P. Multimodal approaches to pain management Nursing. 2017 Mar; 41(3): 60-1.

18. Young KD. Pediatric procedural pain. Ann Emerg Med. 2005 Feb;45(2):160-171.

19. Anand K, Stevens B, McGrath PJ. Pain in neonates and infants: pain research and clinical management series. New York, USA: Elsevier; 2007.

20. Fitzgerald $M$, Beggs $S$. The neurobiology of pain: developmental aspects. Neuroscientist. 2001 Jun;7(3):246-57.

21. Davidson AJ. Neurotoxicity and the need for anesthesia in the newborn: does the emperor have no clothes? Anesthesiology. 2012 Mar;116(3):50750-9.

22. Bhutta AT, Anand KJ. Vulnerability of the developing brain. Neuronal mechanisms. Clin Perinatol. 2002 Sep;29(3):35772.

23. Fitzgerald $M$. What do we really know about newborn infant pain? Exp Physiol. 2015 Dec;100(12):1451-7.

24. Soriano SG, Anand KJ. Anesthetics and brain toxicity Current Opinion in Anesthesiology 2005; 18:293-97.

25. Lundeberg S, Lundeberg T. Pain in infants and children-Physiological background and clinical aspects. Acupuncture and Related Therapies 1 (2013) 46-9.

26. Fitzgerald M, Walker SM. Infant pain management: a developmental neurobiological approach. Nat Clin Pract Neurol. 2009 Jan; $5(1): 35-50$

27. Fabrizi L, Slater R, Worley A, et al. A Shift in Sensory Processing that Enables the Developing Human Brain to Discriminate Touch from Pain. Current Biology. 2011;21(18):155258.

28. Talos DM, Follett PL, Folkerth RD, et al. Developmental regulation of AMPA receptor subunit expression in forebrain and relationship to regional susceptibility to hypoxic/ischemic injury: Part II. Human cerebral white matter and cortex. Steward $O$, ed. The Journal of comparative neurology. 2006 ; 497(1):61-77.

29. Johnston CC, Stremler RL, Stevens BJ, Horton LJ. Effectiveness of oral sucrose and simulated rocking on pain response in preterm neonates. Pain. 1997 Aug;72(1-2):193-99.

30. Ruda MA, Ling $Q D$, Hohmann AG, Peng YB, Tachibana T. Altered nociceptive neuronal circuits after neonatal peripheral inflammation. Science. 2000 Jul 28;289(5479):628-31.

31. Taddio A, Katz J, Ilersich AL, Koren G. Effect of neonatal circumcision on pain response during subsequent routine vaccination. Lancet. 1997 Mar 1;349(9052):599-603.

32. Fabrizi L, Williams $G$, Lee A, Meek J, Slater R, Olhede S, Fitzgerald M. Cortical activity evoked by an acute painful tissue-damaging stimulus in healthy adult volunteers. J Neurophysiol. 2013 May;109(9):2393-403.
33. Vinall J, Grunau RE. Impact of repeated procedural pain-related stress in infants born very preterm. Pediatr Res. 2014 May;75(5):584-87.

34. Buntinx $M$, Moreels $M$, Vandenabeele $F$ Lambrichts $I$, Raus J, Steels P, Stinissen P, Ameloot M. Cytokine-induced cell death in human oligodendroglial cell lines: I. Synergistic effects of IFN-gamma and TNF-alpha on apoptosis. J Neurosci Res. 2004 Jun 15;76(6):834-45.

35. Slater L, Asmerom $Y$, Boskovic DS, Bahjri K, Plank MS Angeles KR, Phillips R, Deming D, Ashwal S, Hougland K, Fayard E, Angeles DM. Procedural pain and oxidative stress in premature neonates. J Pain. 2012 Jun;13(6):590-97.

36. Brummelte S, Grunau RE, Chau V, Poskitt KJ, Brant R, Vinall J, Gover A, Synnes AR, Miller SP. Procedural pain and brain development in premature newborns. Ann Neurol. 2012 Mar;71(3):385-96

37. Dührsen L, Simons SH, Dzietko M, Genz K, Bendix I, Boos V, Sifringer M, Tibboel D, Felderhoff-Mueser U. Effects of repetitive exposure to pain and morphine treatment on the neonatal rat brain. Neonatology. 2013;103(1):35-43.

38. Ranger M, Chau CM, Garg A, Woodward TS, Beg MF, Bjornson B, Poskitt K, Fitzpatrick K, Synnes AR, Miller SP, Grunau RE. Neonatal pain-related stress predicts cortical thickness at age 7 years in children born very preterm. PloS One. 2013 Oct 18;8(10):76702.

39. Ranger M, Grunau RE. Early repetitive pain in preterm infants in relation to the developing brain. Pain Manag. 2014 Jan:4(1):57-67.

40. Doesburg SM, Chau CM, Cheung TP, Moiseev A, Ribary U, Herdman AT, Miller SP, Cepeda IL, Synnes A, Grunau RE. Neonatal pain-related stress, functional cortical activity and visual-perceptual abilities in school-age children born at extremely low gestational age. Pain. 2013 Oct;154(10):1946-52.

41. Jacobson RM, Swan A, Adegbenro A, Ludington SL, Wollan PC, Poland GA; Vaccine Research Group. Making vaccines more acceptable--methods to prevent and minimize pain and other common adverse events associated with vaccines. Vaccine. 2001 Mar 21;19(17-19):2418-27.

42. Taddio A, Ilersich AL, Ipp M, Kikuta A, Shah V; HELPinKIDS Team. Physical interventions and injection techniques for reducing injection pain during routine childhood immunizations: systematic review of randomized controlled trials and quasi-randomized controlled trials. Clin Ther. 2009;31 Suppl 2:48-76.

43. Linking opportunities generatino inter-professional collaboration. The official journal of the new zealand college of primary health care nurses, NZNO. June, 2016 15: 2. Avalible from http://www.who.int/immunization/sage/meetings/2014/october/1_Report_WOR

44. Taddio A, Ipp M, Thivakaran S, Jamal A, Parikh C, Smart S, Sovran J, Stephens D, Katz J. Survey of the prevalence of immunization non-compliance due to needle fears in children and adults. Vaccine. 2012 Jul 6;30(32):4807-12.

45. Kennedy A, Basket M, Sheedy K. Vaccine attitudes, concerns, and information sources reported by parents of young children: results from the 2009 HealthStyles survey. Pediatrics. 2011 May;127 Suppl 1:92-9.

46. WHO position paper: Reducing pain at the time of vaccination. September 2015. Wkly Epidemiol Rec. 2015 Sep 25;90(39):505-10.

47. Taddio A, Ho T, Vyas C, Thivakaran S, Jamal A, Ilersich AF, Hogan ME, Shah V. A randomized controlled trial of clinician-led tactile stimulation to reduce pain during vaccination in infants. Clin Pediatr (Phila). 2014 Jun;53(7):639-44. 
48. Beirne PV, Hennessy S, Cadogan SL, Shiely F, Fitzgerald T, MacLeod F. Needle size for vaccination procedures in children and adolescents. Cochrane Database Syst Rev. 2015 Jun 18;(6):CD010720.

49. Taddio A, McMurtry CM, Shah V, Riddell RP, Chambers CT, Noel M, MacDonald NE, Rogers J, Bucci LM, Mousmanis $P$, Lang E, Halperin SA, Bowles S, Halpert C, Ipp M, Asmundson GJ, Rieder MJ, Robson K, Uleryk E, Antony MM, Dubey V, Hanrahan A, Lockett D, Scott J, Votta Bleeker E; HELPinKids\& Adults. Reducing pain during vaccine injections: clinical practice guideline. CMAJ. 2015 Sep 22;187(13):975-82.

50. Taddio A, Wong H, Welkovics B, Ilersich AL, Cole M, Goldbach M, Ipp M. A randomized trial of the effect of vaccine injection speed on acute pain in infants. Vaccine. $2016 \mathrm{Sep}$ 7;34(39):4672-7.

51. Slater R, Worley A, Fabrizi L, Roberts S, MeekJ, Boyd S, Fitzgerald M. Evoked potentials generated by noxious stimulation in the human infant brain. EurJPain. 2010Mar;14(3):321-26.

52. Pillai Riddell RR, Racine NM, Gennis HG, Turcotte K, Uman LS, Horton RE, Ahola Kohut S, Hillgrove Stuart J, Stevens $B$, Lisi DM. Non-pharmacological management of infant and young child procedural pain. Cochrane Database Syst Rev. 2015 Dec 2;(12): CD006275.

53. Levene I. Question 2: does topical local anaesthetic reduce pain from vaccinations in infants? Arch Dis Child. 2014 Nov;99(11):1057-8.

54. Gupta NK, Upadhyay A, Agarwal A, Goswami G, Kumar $J$, Sreenivas V. Randomized controlled trial of topical EMLA and breastfeeding for reducing pain during $w D P T$ vaccination. Eur J Pediatr. 2013 Nov;172(11):1527-33.

55. Vinall J, Miller SP, Synnes AR, Grunau RE. Parent behaviors moderate the relationship between neonatal pain and internalizing behaviors at 18 months corrected age in children born very prematurely. Pain. 2013 Sep;154(9):1831-39.

56. Hall RW, Anand KJ. Pain management in newborns. Clin Perinatol. 2014 Dec;41(4):895-924.

57. Johnston CC, Stevens B, Craig KD, Grunau RV. Developmental changes in pain expression in premature, full-term, two- and four-month-old infants. Pain. 1993 Feb;52(2):201-8.

58. Johnston C, Campbell-Yeo M, Disher T, Benoit B, Fernandes $A$, Streiner D,Inglis D, Zee R. Skin-to-skin care for procedural pain in neonates. CochraneDatabase Syst Rev. 2017 Feb 16;2:CD008435.

59. Fishman S, Ballantyne J, Bonica JJ.Bonica's Management of Pain. Philadelphia, PA: Lippincott Williams \& Wilkins; 2010.

60. Melzack R, Wall PD. Pain mechanisms: a new theory. Science. 1965 Nov 19;150(3699):971-79.

61. Purves D, Augustine G, Fitzpatrick D, et al.Neuroscience. 2nd ed. Sunderland, MA: Sinauer Associates; 2001.

62. Romanò CL, Cecca E. A new method to reduce pin-prick pain of intra-muscular and subcutaneous injections. Minerva Anestesiol. 2005 Oct;71(10):609-15.

63. Hogan ME, Probst J, Wong K, Riddell RP, Katz J, Taddio A. A randomized-controlled trial of parent-led tactile stimulation to reduce pain during infant immunization injections. Clin $J$ Pain. 2014 Mar;30(3):259-65.
64. Alavi NM. Effectiveness of acupressure to reduce pain in intramuscular injections. Acute Pain. 2007;9(4):201-5.

65. Jain S, Kumar P, McMillan DD. Prior leg massage decreases pain responses to heel stick in preterm babies. J Paediatr Child Health. 2006 Sep;42(9):505-8.

66. Gibbins S, Stevens B. Mechanisms of sucrose and non-nutritive sucking in procedural pain management in infants. Pain Res Manag. 2001 Spring;6(1):21-8.

67. Barrett T, Kent $S$, Voudouris N. Does melatonin modulate beta-endorphin, corticosterone, and pain threshold? Life Sci. 2000;66(6):467-76.

68. Blass EM. Milk-induced hypoalgesia in human newborns. Pediatrics. 1997 Jun;99(6):825-29.

69. Shah PS, Herbozo C, Aliwalas LL, Shah VS. Breastfeeding or breast milk for procedural pain in neonates. Cochrane Database Syst Rev. 2012 Dec 12;12:CD004950.

70. Rosali L, Nesargi S, Mathew S, Vasu U, Rao SP, Bhat S. Efficacy of expressed breast milk in reducing pain during $R O P$ screening--a randomized controlled trial. J Trop Pediatr. 2015 Apr;61(2):135-8.

71. Liaw JJ, Zeng WP, Yang L, Yuh YS, Yin T, Yang MH. Nonnutritive sucking and oral sucrose relieve neonatal pain during intramuscular injection of hepatitis vaccine. J Pain Symptom Manage. 2011 Dec;42(6):918-30.

72. Harrison D, Stevens B, Bueno M, Yamada J, Webber TA, Beyene J, Ohlsson A. Efficacy of sweet solutions for analgesia in infants between 1 and 12 months of age: a systematic review. Arch Dis Child. 2010 May; 2-8.

73. Marín Gabriel MÁ, del Rey Hurtado de Mendoza B, Jiménez Figueroa L, Medina V, Iglesias Fernández B, Vázquez Rodríguez M, Escudero Huedo V, Medina Malagón L. Analgesia with breastfeeding in addition to skin-to-skin contact during heel prick. Arch Dis Child Fetal Neonatal Ed. 2013 Nov;98(6):F499-503.

74. Yilmaz G, Caylan N, Oguz M, Karacan CD. Oral sucrose administration to reduce pain response during immunization in 16-19-month infants: a randomized, placebo-controlled trial. Eur J Pediatr. 2014 Nov;173(11):1527-32.

75. Committee On Fetus And Newborn And Section On Anesthesiology And Pain Medicine. Prevention and Management of Procedural Pain in the Neonate: An Update. Pediatrics. 2016 Feb; 137(2):20154271.

76. Stevens B, Yamada J, Lee GY, Ohlsson A. Sucrose for analgesia in newborn infants undergoing painful procedures. Cochrane Database Syst Rev. 2013 Jan 31;(1):CD001069.

77. Anand K, Stevens B, McGrath PJ. Pain in neonates and infants: pain research and clinical management series. New York, USA: Elsevier; 2007.

78. Guideline statement: management of procedure-related pain in children and adolescents. J Paediatr Child Health. 2006 Feb;42 Suppl 1:1-29.

79. Taddio A, Manley J, Potash L, Ipp M, Sgro M, Shah V. Routine immunization practices: use of topical anesthetics and oral analgesics. Pediatrics. 2007 Sep;120(3): 637-43. 